\title{
Serological survey of Neospora caninum in dairy herds from Parauapebas, State of Pará
}

\section{Inquérito soroepidemiológico sobre Neospora caninum em rebanhos leiteiros de Parauapebas, Estado do Pará}

\author{
Clovis Laurindo Silva ${ }^{1 *}$; José Arimatéa Freitas²; João Luis Garcia3; \\ Cláudio Vieira Araújo ${ }^{4}$; Dauton Luiz Zulpo ${ }^{5}$; Ivo Alexandre leme Cunha ${ }^{6}$
}

\begin{abstract}
Neospora caninum is a coccidian protozoan that affects cattle worldwide causing economic losses. To survey the frequency of anti- $N$. caninum antibodies in dairy herds in the municipality of Parauapebas, Southeast of Pará, samples of 465 sera from 45 farms were subjected to indirect immunofluorescence assay (cutoff 1:100). Anti- $N$. caninum antibodies were found with a frequency of $13,33 \%$ with the following titer distribution: 27 (43,55\%) for titer 100; $14(22,58 \%)$ for $200 ; 16(25,80 \%)$ for 400 , and $5(8,07 \%)$ for 800 ; no serum titers more than 800 was noted, but at least one positive animal was present in most farms. The highest frequency occurred among females, with no significant difference in frequency between the sexes (Fisher exact test $=0,59, \mathrm{P}=0,99$ ); 2-year-old animals had the highest frequency, although their numbers were lesser than those aged $>5$ years, with no significant difference in frequency between the age groups $\left(\chi^{2}=2,1, \mathrm{P}=0,71\right)$. No significant difference was observed between the frequency and occurrence of abortion $\left(\chi^{2}=2,3, \mathrm{P}=0,13\right)$ and frequency and presence of dogs in the farms $\left(\chi^{2}=0,26, P=0,60\right)$. Actions toward health monitoring are recommended to prevent the entry of new sources of $N$. caninum and to control its spread within herds.
\end{abstract}

Key words: Neosporosis, Neospora caninum, dairy cattle, Brazilian Amazon, IFAT

\section{Resumo}

Neospora caninum é um protozoário coccídio de difusão mundial que causa prejuízos econômicos no criatório. Para levantar a frequência de anticorpos anti- $N$. caninum em rebanhos leiteiros no município de Parauapebas, Região Sudeste do Estado do Pará, 465 amostras de soros procedentes de 45 propriedades foram submetidas à reação de imunofluorescência indireta (ponto de corte 1:100). Foi determinada a frequência de $13,33 \%$ de anticorpos anti- $N$. caninum com a seguinte distribuição de títulos: $27(43,55$ \%) no título $100 ; 14(22,58 \%)$ no $200 ; 16(25,80 \%)$ no 400 e $5(8,07 \%)$ no 800 , nenhum soro com título $>800$ e pelo menos um animal positivo na maioria das propriedades. A maior frequência ocorreu entre as fêmeas, sem diferença significativa na frequência entre os sexos (Teste exato de Fisher=0,59, $\mathrm{P}=0,99)$; animais de dois anos apresentaram a maior frequência, embora seu número fosse menor que os de idade $>5$ anos, sem diferença significativa na frequência entre faixas etárias $\left(\left(\chi^{2}=2,1, p=0,71\right)\right.$; não foi

1 M.e em Sanidade Animal, Prefeitura Municipal de Parauapebas, PA, Brasil. E-mail: clovislaurindodasilva@yahoo.com.br

2 Prof. Dr. Adjunto aposentado, Instituto de Saúde e Produção Animal; Universidade Federal Rural da Amazônia, UFRA, Belém, AM, Brasil. E-mail: jaf.bel@terra.com.br

3 Prof. de Parasitologia Veterinária, Dept ${ }^{\circ}$ de Medicina Veterinária Preventiva, Universidade Estadual de Londrina, UEL, Londrina, PR Brasil. E-mail: jlgarcia@uel.br

4 Prof. do Curso de Zootecnia do Campus Universitário de Sinop, Universidade Federal de Mato Grosso, UFMT, Sinop, MT, Brasil. E-mail: araujocv@bol.com.br

5 M.e, UEL, Londrina, PR, Brasil. E-mail: dauton.zulpo@pucpr.br

6 Discente do Curso de Doutorado em Ciência Animal, CCA/UEL, Londrina, PR, Brasil. E-mail: ivoleme@gmail.com Author for correspondence 
observada diferença significativa entre frequência e ocorrência de aborto $\left(\chi^{2}=2,3, p=0,13\right)$ e frequência e presença de cães nas propriedades $\left(\chi^{2}=0,26, \mathrm{p}=0,60\right)$. Ações de vigilância sanitária são recomendadas para prevenir a entrada de novas fontes de $N$. caninum e controlar sua difusão nos rebanhos.

Palavras-chave: Neosporose, Neospora caninum, bovinos leiteiros, Amazônia Brasileira, RIFI

\section{Introduction}

Neosporosis, a disease of economic and worldwide significance, is caused by Neospora caninum, and it affects livestock and animals such as carnivores and other wildlife (DUBEY; LINDSAY, 1993; DUBEY, 2003). N. caninum is a complex protozoan coccidia and an obligate intracellular parasite. Dog and coyote are the definitive hosts of this parasite, and cattle are its intermediates hosts (TAYLOR; WEBSTER, 1998; DUBEY, 2003; GONDIM; MCALLISTER; ZEMLICKA, 2004).

N. caninum occurs in the United States, Canada, UK, Australia, and other countries such as Brazil, and is associated with reproductive disorders, early disposal of animals, and reduced milk production, resulting in marked economic losses in the livestock industry (FARIAS, 2002; DUBEY, 2003; CORBELLINI, 2005).

In Brazil, N. caninum infection was detected in cattle, sheep, goats, and buffaloes (AGUIAR et al., 2005; VOGEL et al., 2006; VARASCHIN et al., 2011), and in buffalo and cattle, in particular, in the state of Pará (MINERVINO et al., 2007; SILVA et al., 2010). However, there is no record of its occurrence among dairy cattle in the southeast region of this state, which is the most important dairy region (FREITAS, 2001) and new agricultural frontier in the Amazon.

Considering the movement of animals in the southeast region and eventually to other regions of the state of Pará, it is necessary to understand the occurrence of this pathogen in regional dairy herds. This study aimed to assess the incidence of anti- $N$. caninum antibodies in dairy bovine cattle in the municipality of Parauapebas, southeast region of the state of Pará.

\section{Materials and Methods}

Serum samples of dairy cattle originating from farms in Parauapebas, southeast region of the state of Pará, were used in this study.

The municipality of Parauapebas $\left(06^{\circ} 03^{\prime} 30^{\prime \prime}\right.$ $\mathrm{S}$ and $49^{\circ} 55^{\prime} 15^{\prime \prime} \mathrm{W}$ ) is characterized by super humid equatorial climate, with $26,35^{\circ} \mathrm{C}$ average temperature and $78 \%$ relative humidity. The rainy season is from November to May, and the dry season, from June to October, with annual rainfall of approximately $2000 \mathrm{~mm}$. Cattle breeding (dairy and beef) is an important economic activity in this region, with about 129000 heads spread across 401 farms that exploit crossbred dairy cattle; daily, 15 000 cows are milked, producing 7 million liters of milk (IBGE, 2007).

The initial selection of properties was based on data from the Brazilian Institute of Geography and Statistics (IBGE, 2007) and Agency of Agricultural Defense of Pará (ADEPARÁ, 2007). Properties with good access facilities, those that maintained exploration of their own dairy herd, had facilities for handling of animals, and whose owners agreed with the research objectives were selected. Thus, 45 properties were selected with an area between 25 and 50 ha, herd size from 10 to 250 animals, and daily milk production of 3-18 L. For sample size calculation, the following formula was used: $\mathrm{n}=\mathrm{Z}_{\alpha}{ }^{2} \times \mathrm{P}(1-\mathrm{P}) / \mathrm{e}^{2}$, where $\mathrm{n}$ is the number of animals; $Z$, value of the normal distribution for a confidence level of $95 \%$; and $\mathrm{P}$, expected prevalence (SAMPAIO, 2007). In order to determine $\mathrm{P}=50 \%$ and the maximum error of $9,5 \%$ of the prevalence, a minimum sample of 443 animals, plus 5\% for losses totaling 465 animals, were assessed.

The animals in each property were randomly selected according to their distribution in the pasture, 
management, breeding system, and activities in the herd; thus, 430 females and 35 males were selected. Blood sampling was conducted by venipuncture, and the separated sera were maintained at $-20^{\circ} \mathrm{C}$ for testing. In order to obtain data of the livestock breeding characteristic, presence of dogs on the property, and incidence of reproductive disorders, a questionnaire survey was conducted in each property.

Anti-N. caninum antibodies were assessed by indirect immunofluorescence assay (IFA) (CONRAD et al., 1993; PARÉ; HIETALA; THURMOND, 1995; DUBEY; LINDSAY, 1993) developed using antigen labeled slides (strain standard tachyzoites, JPA1) with a cutoff dilution 1:100, and previously assessed sera as positive and negative controls.
To understand the association between the frequency and associated factors assayed, Chisquare contingency and compliance test and Fisher exact test were used (AYRES et al., 2007). $\mathrm{P}<0.05$ was considered significant

\section{Results and Discussion}

The frequency of anti- $N$. caninum antibodies in dairy herds in Parauapebas reached 13,33\% (Table 1), ranging between $7,14 \%$ and $41,67 \%$, with a statistically significant difference between positive and negative animals $\left(\chi^{2}=250,1, P=0,0001\right)$; 30 farms had at least one positive animal within the selected cutoff point (1:100). Minervino et al. (2007) showed similar and proximate frequencies of $19,20 \%$ and $17,50 \%$, respectively, with the same cut-off point, in beef and dairy cattle in the municipality of Santarém, Pará.

Table 1. Frequency of anti-Neospora caninum antibodies in dairy cattle in the municipality of Parauapebas.

\begin{tabular}{ccc}
\hline Result & Simple frequency & Frequency (\%) \\
\hline Positive & 62 & 13,33 \\
Negative & 403 & 86,67 \\
\hline Total & 465 & 100,00 \\
\hline
\end{tabular}

$\chi^{2}=250,1 ; \mathrm{P}<0,0001$.

Source: Elaboration of the authors.

Several other studies have shown frequencies similar to the ones in the present study but with different cutoffs. Gondim et al. (1999), Costa et al. (2001), Ogawa et al. (2005) and Santos et al. (2005) detected frequencies of $14,09 \%, 16,83 \%, 12,00 \%$, and $14,30 \%$ with a cutoff of $1: 200$, respectively, in dairy cattle in Bahia, cows for slaughter from the states of São Paulo and Minas Gerais, dairy cattle from northern Paraná, and dairy cows with aborted calves in the north of Paraná. Aguiar et al. (2005) obtained the following frequencies at a 1:25 cutoff: $11,20 \%$ for dairy cattle, $9,50 \%$ for beef cattle, and $9,70 \%$ for dual purpose cattle reared in the city of Monte Negro, Rondônia. However, Ragozo et al.
(2003), by using the same cutoff, obtained higher frequencies: $24,43 \%$ (for dairy cattle) and 19,16\% (in beef cattle) in six Brazilian states. Rezende et al. (1999) sampled dairy cattle in the northeastern region of the state of São Paulo, and obtained $22,22 \%$ frequency with a cutoff of $1: 100$.

Higher frequencies as $62,90 \%, 40,91 \%$, and $50,74 \%$ were determined by Belo et al. (1999), Silva et al. (2010), and Teixeira et al. (2010), respectively, at a cutoff at 1:200, in six dairy herds with a history of miscarriage in the northeastern region of São Paulo, in buffaloes and dairy cattle from 13 municipalities in Pará, and in three microregions of the state of Maranhão. 
Sartor et al. (2005) obtained higher frequencies of $35,54 \%$ and $20,00 \%$, respectively, in dairy and beef cattle in Presidente Prudente, SP, by using ELISA. However, by using indirect ELISA, Vogel et al. (2006) showed frequencies similar to that in the present study, i.e., $11,40 \%$ and $14,60 \%$, in cattle and buffaloes in Rio Grande do Sul.

A low frequency of $3,20 \%$ in sheep in 16 municipalities of Rio Grande do Sul, was also detected by Vogel et al. (2006), through the Indirect ELISA test. A relatively low frequency $(7,70 \%)$ was found in beef cows in the state of Mato Grosso do Sul, by using the ELISA test (ANDREOTTI; PINCKNEY; GOMES, 1999).
In this study, the largest number of positive samples were noted in the 100 titer (43,55\% of sera), followed by 400 (25,81\% of the samples), and the lowest in the 800 (Table 2) $\left(\chi^{2}=15,81, \mathrm{P}<0,001\right)$.

The highest number of positive samples by Ragozo et al. (2003), 24,30\%, was for sera of beef and dairy cattle from six Brazilian states at 25 titer. On the other hand, Teixeira et al. (2010) obtained $32,04 \%$ in dairy cattle from three micro-regions in the state of Maranhão in 400 titer. In buffaloes reared in Pará, $46,04 \%$ of the positive sera were in the $\geq 800$ titer, while $46,51 \%$ of goat sera from the southern region of Minas Gerais were in 50 titer (GENNARI et al., 2005; VARASCHIN et al., 2011). In cattle reared in Santarém, Pará, the largest number of positive samples, $33,30 \%$, was in the 200 titer (MINERVINO et al., 2007).

Table 2. Frequency distribution of anti-Neospora caninum antibodies sera by titer.

\begin{tabular}{ccc}
\hline Titer & Simple frequency & Frequency $(\%)$ \\
\hline 100 & 27 & 43,55 \\
200 & 14 & 22,58 \\
400 & 16 & 25,81 \\
800 & 5 & 8,06 \\
\hline Total & 62 & 100,00 \\
\hline
\end{tabular}

$\chi^{2}=1,81 ; \mathrm{P}<0,001$.

Source: Elaboration of the authors.

Dubey and Lindsay (1993) considered that the 800 titer is high, suggestive of active infection. In this study, $8,06 \%$ of the sera reacted in the 800 titer, whereas in the study by Ragozo et al. (2003), 15,34\% of the sera were found in $\geq 800$ titer; therefore, from our results as well as the statement by Dubey and Lindsay (1993), the sampled animals could be in the acute phase of infection.

The frequencies showed by Aguiar et al. (2005) were similar to those in the present study, after considering the differences in cutoffs (1:25 and 1:100, respectively). This similarity can be attributed to the size of the property and type of animal farming in the breeding farms of the two municipalities. Higher number of seropositive animals was found on the farms of Monte Negro, $\mathrm{RO}$, which has more than 25 ha, similar to the area of properties in Parauapebas that ranges from 25 to 50 ha in the two counties where extensive breeding system is practiced.

No statistically significant difference was noted between the frequency of antibodies and sex of the animals (Fisher exact test $=0,59, \mathrm{P}=0,99$ ) in the present study, even with higher percentage of females in the sample (Table 3). Teixeira et al. (2010) also found no significant association between gender and frequency of antibodies in dairy cattle from three micro-regions of Maranhão; however, Varaschin 
et al. (2011) observed an association between sex and frequency and between breed and frequency in goats in southern Minas Gerais. Corbellini et al. (2000) claim that $N$. caninum has no predilection for sex or breed. We could not compare breeds in this study, because all the animals were crossbred; however, we found a small difference in frequency between the sexes, as $11,43 \%$ of positive cattle were males, while 13,49\% were females (Table 3).

Table 3. Frequency of anti-Neospora caninum antibodies according to the sex of the animals.

\begin{tabular}{ccccccc}
\hline \multirow{2}{*}{ Sex } & \multicolumn{2}{c}{ Positive } & \multicolumn{2}{c}{ Negative } & \multirow{2}{*}{ Total } \\
\cline { 2 - 5 } & $\mathrm{N}$ & $\%$ & $\mathrm{n}$ & $\%$ & \\
\hline Female & 58 & 13,49 & 372 & 86,51 & 430 \\
Male & 4 & 11,43 & 31 & 88,57 & 35 \\
\hline Total & 62 & 13,33 & 403 & 86,67 & 465 \\
\hline
\end{tabular}

Fisher exact test $=0,59(\mathrm{P}=0,99)$.

Source: Elaboration of the authors.

Among the animals from Parauapebas, the 2-year age group showed the highest frequency of antibodies, i.e., 19,23\% (Table 4), although the number of animals was lower in the age group of $>5$ years. However, no significant difference was noted between frequency and age group $\left(\chi^{2}=2,1\right.$,
$\mathrm{P}=0,71$ ). Teixeira et al. (2010) also found no significant association between the anti- $N$. caninum antibodies and age groups of dairy cattle from three micro-regions of Maranhão; however, Varaschin et al. (2011) showed a significant association between antibody frequency and age of goats in southern Minas Gerais.

Table 4. Frequency of anti-Neospora caninum antibodies by age of the animals.

\begin{tabular}{cccccc}
\hline \multirow{2}{*}{ Age range(years) } & \multirow{2}{*}{ Animals(n) } & \multicolumn{2}{c}{ Positive animals } & \multicolumn{2}{c}{ Negative animals } \\
\cline { 3 - 6 } & & $\mathrm{N}$ & $\%$ & $\mathrm{n}$ & $\%$ \\
\hline$\leq 1$ & 41 & 6 & 14,63 & 35 & 85,37 \\
2 & 52 & 10 & 19,23 & 42 & 89,77 \\
3 & 63 & 8 & 12,70 & 55 & 87,30 \\
4 & 65 & 7 & 10,77 & 58 & 89,23 \\
$>5$ & 244 & 31 & 12,70 & 213 & 87,30 \\
\hline Total & 465 & 62 & 13,33 & 403 & 86,67 \\
\hline
\end{tabular}

$\chi^{2}=2,1 ; P=0,71$.

Source: Elaboration of the authors.

Ragozo et al. (2003) observed higher frequency $(26,20 \%)$ for cattle aged $>24$ months in dairy cattle in six Brazilian states, but could not conclude that the difference between frequency and age group was statistically significant, because of the smaller number of animals in the 0-24 months group, although they observed an increase in seropositivity from the 24-48-months group to the 48-72-months group. In sheep from southern Minas Gerais, a higher frequency of antibodies in animals over 6 months of age (ALMEIDA et al., 2007) was observed. All these results differ from the present study, where no statistically significant difference in frequency was noted among age groups, even though the highest frequencies occurred in the 2-year age group $(19,23 \%)$ followed by the $\leq 1$-year age group $(14,63 \%)$. 
Ragozo et al. (2003) also observed increased anti-N. caninum antibody frequency with increasing age of the animals, suggesting that age is a potential risk factor for $N$. caninum infection, unlike the results obtained in the present study, in which there was no increased frequency of antibodies with increasing age of the animals.

The data collected indicated that 50 of the seropositive animals were from farms where cases of abortions occurred, but the animals were not those that had abortions, and no statistically significant difference $\left(\chi^{2}=2,3, \mathrm{P}=0,13\right)$ between frequency and abortion was observed.

In accordance with Aguiar et al. (2005) no significant difference between the frequency of anti-N. caninum antibodies and reproductive problems in cattle from Monte Negro, RO was observed. Similarly, Ogawa et al. (2005) found no association between frequency and reproductive problems in dairy cattle from the northern region of Paraná, which was confirmed in goats in southern Minas Gerais by Varaschin et al. (2011).

In beef herds of Mato Grosso do Sul, anti- $N$. caninum antibody frequency of 7,80\% was obtained using ELISA, which increased considerably to $43,00 \%$ in herds with history of abortions (ANDREOTTI; PINCKNEY; GOMES, 1999). According to Belo et al. (1999), anti-N. caninum antibodies were detected in $62,90 \%$ of cattle females of six dairy farms with history of abortion in the northeastern region of São Paulo.

In most of the properties of Parauapebas, one or more dogs were observed to be wandering freely around the breeding area, but no significant association $\left(\chi^{2}=0,26, \mathrm{P}=0,60\right)$ was observed between the antibody frequency and wandering dogs. Aguiar et al. (2005) and Ogawa et al. (2005) also found no significant association between frequency and presence of dogs near the cattle breeding facilities (dairy, beef, and dual purpose) and dairy cattle, respectively, in Monte Negro, RO, and in the northern region of Paraná. Approximately $90,00 \%$ of the positive sera were from farms with dogs, of which $75,80 \%$ were set loose and $69,35 \%$ consumed raw meat and carcasses, which suggest that these dogs could be infected and are the main disseminating agents of $N$. caninum among farmed cattle in the municipality.

Ogawa et al. (2005) noted no statistically significant difference between the frequency of anti- $N$. caninum antibodies and presence of dogs in the dairy cattle farms in the northern state of Paraná. However, in several other studies, a significant association among antibody frequency, abortion, and presence of dogs on properties was noted, showing that such cohabitation increases the frequency of $N$. caninum in both the species (PARÉ et al., 1998). Another study showed postnatal (horizontal) infection caused by food and water contaminated with oocysts released through the feces of the dogs, associating the abortions due to $N$. caninum infection to the presence of dogs on the properties (FARIAS, 2002).

Among other factors, the presence and number of dogs per property can directly influence the number of positive animals. In semi-intensive breeding systems, dogs have higher access to paddocks and other husbandry facilities and animal feed, and they consume waste from births and carcasses, and excrete the oocysts into the environment. A significant association was found between the prevalence of $N$. caninum and number of dogs on the properties $(\mathrm{P}=0,02$, OR 1,17) (CORBELLINI, 2005).

Considering the movement of animals in the southeastern region of the state of Pará and the high frequency of anti- $N$. caninum antibodies detected in farms in the municipality of Parauapebas, the adoption of health and surveillance measures of herds is justified, to prevent the entry of new sources of infection of this pathogen in herds and to control its dissemination in regional breeding farms. 


\section{Acknowledgments}

To the State University of Londrina and the Municipal Rural Production of Parauapebas for supporting the study.

\section{References}

AGÊNCIA DE DEFESA AGROPECUÁRIA DO ESTADO DO PARÁ - ADEPARÁ. Unidade local de saúde animal e vegetal de parauapebas. TC2 da campanha de novembro de 2007. [S.1.: s.n.], 2007.

AGUIAR, D. M.; CAVALCANTE, G. T.; CAÑÓNFRANCO, W. A.; RODRIGUES, D. P. C.; LABRUNA, M. B.; CAMARGO, L. M. A.; GENNARI, S. M. Prevalência de anticorpos anti-Neospora caninum em bovinos, ovinos e cães da Amazônia Ocidental Brasileira, Estado de Rondônia. In: I FÓRUM BRASILEIRO DE ESTUDOS SOBRE Neospora caninum, 2005, São Paulo. Anais... São Paulo: Colégio Brasileiro de Parasitologia Veterinária, 2005. p. 33-35.

ALMEIDA, M. C. S.; FRANCISCO, W. E.; STEFANO, E.; PITUCO, E. M.; DEL FAVA, C.; OKUDA, L. H. Ocorrência de neosporose em ovinos (Ovies aries Linnaeus, 1758) no Brasil. In: SIMPÓSIO DE ENFERMIDADE DE CAPRINOS E OVINOS, 2.; CICAM, 5., 2007, São Paulo. Anais... São Paulo: [s.n.], 2007. p. 28.

ANDREOTTI, R.; PINCKNEY, R.; GOMES, A. Diagnóstico sorológico de Neospora caninum em rebanho bovino de corte de Mato Grosso do Sul. In. SEMINÁRIO BRASILEIRO DE PARASITOLOGIA, 11., 1999, Salvador. Anais.... Salvador, 1999. p. 226-227.

AYRES, M.; AYRES JÚNIOR, M.; AYRES, D. L; SANTOS, A. S. Bio Estat 5.0. Aplicações estatísticas nas áreas das ciências biológicas e médicas. Belém: Instituto de Desenvolvimento Sustentável Mamirauá, 2007. 364 p.

BELO, M. A. A.; REZENDE, P. C. B.; SOUZA, L. M.; COSTA, A. J. Presença de anticorpos contra Neospora caninum em bovinos com histórico de abortos não diagnosticados etiologicamente. In: SEMINÁRIO BRASILEIRO DE PARASITOLOGIA VETERINÁRIA, 11., 1999, Salvador. Anais... Salvador: CBPV, 1999. p. 229.

CORBELLINI, L. G.; DRIEMEIER, D.; CRUZ, C.; DIAS, M. M. Aborto bovino por Neospora caninum no Rio Grande do Sul. Ciência Rural, Santa Maria, v. 30, n. 5, p. 863-868, 2000.

CORBELLINI, L. G. Neosporose bovina: estudo de fatores de risco em 60 propriedades leiteiras no estado do
Rio Grande do Sul e levantamento de causas de aborto bovino com ênfase em Neospora caninum. Acta Scientiae Veterinariae, Porto Alegre, v. 33, n. 2, p. 231-232, 2005.

CONRAD, P. A.; SVERLOW, K. W.; ANDERSON, M. A.; ROWE, J.; BONDURANT, R.; TUTER, G.; BREITMEYER, R.; PALMER, C.; THURMOND, M.; ARDANS, A.; DUBEY, J. P.; DUHAMEL, G.; BARR, B. C. Detection of serum antibody responses in cattle with natural or experimental Neospora infections. Journal of Veterinary Diagnostic Investigation, California, v. 5, n. 4, p. 572-578, 1993.

COSTA, G. N.; CABRAL, D. D.; VARANDAS, N. P.; SOBRAL, E. A.; BORGES, F. A.; CASTAGNOLLI, K. C. Frequência de anticorpos anti-Neospora caninum e anti-Toxoplasma gondii em soros de bovinos pertencentes aos estados de São Paulo e de Minas Gerais. Semina: Ciências Agrárias, Londrina, v. 22, n. 1, p. 61-66, 2001.

DUBEY, J. P.; LINDSAY, D. S. Neosporosis. Parasitology Today, Londres, v. 9, n. 12, p. 452-458, 1993.

DUBEY, J. P. Review of Neospora caninum and neosporosis in animals. Korean Journal of Parasitology, Seoul, v. 41, n. 1, p. 1-16, 2003.

FARIAS, N. A. R. Neosporose - uma enfermidade a ser estudada. Ciência e Tecnologia Veterinária, Pelotas, v. 1, n. 1, p. 5-14, 2002.

FREITAS, J. A. Qualidade do leite frente ao beneficiamento e obtenção de derivados. In: SEMINÁRIO DE ZOOTECNIA DA FACULDADE DE CIÊNCIAS AGRÁRIAS DO PARÁ PRODUÇÃO LEITEIRA NA AMAZÔNIA: DESAFIOS E PERSPECTIVAS, 2001, Belém. Anais... Belém: FCAP, 2001. p. 105-110.

GENNARI, S. M.; RODRIGUES, A. A. R.; VIANA, R. B.; CARDOSO, E. C. Occurrence of anti-Neospora caninum antibodies in water buffaloes (Bubalus bubalis) from the Northern region of Brazil. Veterinary Parasitology, Amsterdam, v. 134, n. 1, p. 169-171, 2005.

GONDIM, L. F. P.; SARTOR, I. F.; HASEGAWA, M.; YAMANE, I. Seroprevalence of Neospora caninum in dary cattle in Bahia, Brazil. Veterinary Parasitology, Amsterdam, v. 86, n. 1, p. 71-75, 1999.

GONDIM, L. F. P.; MCALLISTER, M. M.; ZEMLICKA, C. Coiyotes (Canis latrans) are definite hosts of Neospora caninum. International Journal for Parasitology, Oxford, v. 34, n. 2, p. 159-161, 2004.

INSTITUTO BRASILEIRO DE GEOGRAFIA E ESTATÍSTICA - IBGE. Censo agropecuário 2007. Rio de Janeiro: IBGE, 2007. Disponível em: <http://www. ibge.Gov.br/cidadesat/topwindow.htm?1>. Acesso em: 14 dez. 2008. 
MINERVINO, A. H. H.; RAGOZO, A. M. A.; MONTEIRO, R. M.; ORTOLANI, R. L.; GENNARI, S. M. Prevalence of Neospora caninum antibodies in cattle from Santarém, Pará. Brazilian Journal of Veterinary Research and Animal Science, São Paulo, v. 84, n. 2, p. 254-256, 2007.

OGAWA, L.; FREIRE, R. L.; VIDOTTO, O.; GONDIM, L. F. P.; NAVARRO, I. T. Ocorrência de anticorpos contra Neospora caninum e Toxoplasma gondii em bovinos leiteiros da região norte do estado do Paraná. Arquivo Brasileiro de Medicina Veterinária e Zootecnia, Belo Horizonte, v. 57, n. 3, p. 312-316, 2005.

PARÉ, J.; HIETALA, S. K.; THURMOND, M. C. Interpretation of an indirect fluorescent antibody test for diagnosis of Neospora sp. infection in cattle. Journal of Veterinary Diagnostic Investigation, Davis, v. 7, n. 2, p. 273-275, 1995.

PARÉ, J.; FECTEAU, G.; FORTIN, M.; MARSOLAIS, G. Seroepidemiology study of Neospora caninum in dairy herds. Journal of the American Veterinary Medical Association, New York, v. 213, n. 11, p. 1595-1598, 1998.

RAGOZO, A. M. A.; PAULA, V. O.; SOUZA, S. L. P.; BERGAMASCHI, D. P.; GENNARI, S. M. Ocorrência de anticorpos anti-Nesopora caninum em soros bovinos procedentes de seis estados brasileiros. Revista Brasileira de Parasitologia Veterinária, São Carlos, v. 12, n. 1, p. 33-37, 2003.

REZENDE, P. C. B.; BELO, M. A. A.; MARCHIORI FILHO, M.; COSTA, A. J.; SILVEIRA, D. M. Anticorpos anti-Neospora caninum em bovinos leiteiros da região nordeste do estado de São Paulo, Brasil. In: SEMINÁRIO DE PARASITOLOGIA VETERINÁRIA, 11., 1999, Salvador. Anais.... Salvador: CBPV, 1999. p. 229.

SAMPAIO, I. B. M. Estatística aplicada à experimentação animal. 3. ed. Belo Horizonte: FEPMVZ, 2007. 264 p.

SANTOS, A. P. M. E.; NAVARRO, I. T.; BRACARENSE, A. P. F. R. L.; FREIRE, R. L.; MARANA, E. R. M.; OGAWA, L.; ALFIERI, A. A.; FREITAS, J. C.; VIDOTTO, O. Dairy abortion associated with Neospora caninum and other infectious agents. Arquivo Brasileiro de Medicina Veterinária e Zootecnia, Belo Horizonte, v. 57, n. 4, p. 545-547, 2005.
SARTOR, I. F.; GARCIA FILHO, A.; VIANNA, L. C.; PITUCO, E. M.; DAL PAI, V.; SARTOR, R. Ocorrência de anticorpos anti-Neospora caninum em bovinos leiteiros e de corte da região de Presidente Prudente, SP. Arquivos do Instituto Biológico, São Paulo, v. 72, n. 4, p. 413-418, 2005.

SILVA, S. P.; MOTA, R. A.; FARIA, E. B.; FERNANDES, E. F. T. S.; SOUSA NETO, O. L.; ALBUQUERQUE, P. P. F.; DIAS, H. L. T. Anticorpos IgG anti-Neospora caninum e Toxoplasma gondii em búfalas (Bubalus bubalis) criadas no estado do Pará. Pesquisa Veterinária Brasileira, Seropédica, v. 30, n. 5, p. 443-446, 2010.

TAYLOR, M. A.; WEBSTER, K. A. Recent advances in the diagnosis in livestock of Cryptosporidium, Toxoplasma, Giardia and other protozoa of veterinary importance. Research in Veterinary Science, Oxford, v. 65, n. 3, p. 183-193, 1998.

TEIXEIRA, W. C.; UZEDA, R. S.; GONDIM, L. F. P.; SILVA, M. I. S.; PEREIRA, H. M.; ALVES, L. C.; FAUSTINO, M. A. G. Prevalência de anticorpos antiNeospora caninum (Apicomplexa: Sarcocystidae) em bovinos leiteiros de propriedades rurais em três microrregiões do Maranhão. Pesquisa Veterinária Brasileira, Seropédica, v. 30, n. 9, p. 729-734, 2010.

VARASCHIN, M. S.; GUIMARÃES, A. M.; HIRSCH, C.; MESQUITA, L. P.; ABREU, C. C.; ROCHA, C. M. B. M.; WOUTERS, F.; MOREIRA, M. C. Fatores associados a soroprevalência de Neospora caninum e Toxoplasma gondii em rebanhos caprinos na região sul de Minas Gerais. Pesquisa Veterinária Brasileira, Seropédica, v. 31, n. 1, p. 53-58, 2011.

VOGEL, F. S. F.; ARENHART, S.; BAUERMAN, F. V.; VIÇOSA, F. Anticorpos anti-Neospora caninum em bovinos, ovinos e bubalinos no Estado do Rio Grande do Sul. Ciência Rural, Santa Maria, v. 36, n. 6, p. 19481951, 2006. 